\title{
WALKING THE TALK Assessing companies' progress from SDG rhetoric to action
}

Three years after the adoption of the Sustainable Development Goals (SDGs), reliable information on how companies are working to contribute to the SDGs remains sparse. This paper uses five general themes (prioritization; integration; ambition; human rights and gender equality; and reporting) to review the SDG engagement of 76 of the world's largest companies. It finds that while uptake of the SDGs by companies is high, there is little evidence of the SDGs changing companies' sustainability strategies with regards to priorities, ambition or transparency. The paper points to good practice for how business can more effectively engage with the SDGs.

Written by Ruth Mhlanga, Uwe Gneiting and Namit Agarwal

\section{Oxfam Discussion Papers}

Oxfam Discussion Papers are written to contribute to public debate and to invite feedback on development and humanitarian policy issues. They are 'work in progress' documents, and do not necessarily constitute final publications or reflect Oxfam policy positions. The views and recommendations expressed are those of the authors and not necessarily those of Oxfam.

For more information, or to comment on this paper, email rhmlanga1@oxfam.org.uk. 


\section{CONTENTS}

Executive Summary

1 Introduction $\quad 5$

Untangling the role of business in delivering the SDGs 5

2 Setting the scene: key trends for business engagement with the SDGS 8

Greater awareness of the SDGs among multinational corporations 8

The business case as the primary appeal for engagement 8

$\begin{array}{ll}\text { A challenging global context } & 9\end{array}$

Calls for more meaningful action $\quad 9$

3 Assessing companies' SDG engagement 10

Summary of findings: More companies are publicly committing to the SDGs 11

The risk of cherry-picking and the absence of robust justification for SDG selection 12

Uneven progress on integrating the SDGs into company strategies 14

$\begin{array}{ll}\text { A lack of new ambitions } & 14\end{array}$

The missing link with the human rights agenda and gender equality 15

$\begin{array}{ll}\text { Reporting: gaps in transparency and accountability } & 17\end{array}$

4 Business and the SDGS: closing the gaps 19

$\begin{array}{ll}\text { Barriers to more meaningful SDG engagement by companies } & 19\end{array}$

$5 \quad$ Shining a light on good practice $\quad 21$

$\begin{array}{ll}\text { Prioritization } & 22\end{array}$

$\begin{array}{ll}\text { Integration } & 22\end{array}$

Ambitious action $\quad 24$

Human rights and gender equality 25

Reporting and accountability 26

$\begin{array}{ll}\text { The way forward } & 28\end{array}$

$\begin{array}{ll}\text { Notes } & 30\end{array}$

$\begin{array}{ll}\text { Acknowledgements } & 36\end{array}$ 


\section{EXECUTIVE SUMMARY}

Business has the potential to play a key role in helping society to achieve the Sustainable Development Goals (SDGs). Yet three years after the adoption of the SDGs, reliable information regarding companies' uptake of and contributions to the goals remains patchy. This paper aims to help fill this gap by offering and analysing evidence, based on a review of public information on the SDG engagements of 76 of the world's largest companies, across a set of sectors that have an important impact on the SDGs. The paper provides an analysis of progress and shortcomings in the way companies have engaged with the SDGs to date, as well as an explanation of what is holding back more meaningful action. In addition, it points to good practice to show how business can more effectively engage with the SDGs.

Our analysis outlines five core concerns:

- Companies display no consistent approach to determining their priority SDGs. SDG priorities appear to mirror companies' existing sustainability priorities instead of being shaped by a robust analysis of companies' impact on the SDGs. The amount of information provided by companies in our sample on how and why certain goals were prioritized was, in most cases, limited to non-existent.

- The SDGs have not substantially changed companies' approach to corporate sustainability. While the majority of companies in our sample have undertaken some level of SDG alignment by linking and mapping their existing work across the SDGs, only two of these companies have made the SDGs the guiding framework for their sustainability strategy.

- Companies have not significantly augmented the ambition of their sustainability strategies as a result of engaging with the SDGs. While about two-thirds of companies in our sample have declared that they are supporting the SDGs, only about half of those companies have information available on new SDG-related actions or targets (often focused on discretionary projects with limited scope).

- Few companies are marrying their human rights commitment with their ambition to contribute to the SDGs. While the vast majority of companies in our sample have a human rights policy, only five of them place a strong emphasis on human rights when articulating their support for the SDGs. Companies thus miss the link between addressing human rights risks and the potential for positive sustainable development outcomes.

- Reporting on the SDGs is limited despite receiving significant attention from companies. More than two-thirds of companies in our sample that are engaging with the SDGs are publishing some kind of reporting information on that engagement. However, since common SDG reporting standards are still in their infancy, reporting data to date has remained inconsistent and limited in its utility for stakeholders.

Our analysis concludes that companies' engagement with the SDGs must substantially improve if business is to have a meaningful role in achieving the SDGs. Three years since the adoption of the goals, we have seen little evidence of companies changing the priorities of their sustainability strategies, or ambition to engage with the SDGs in a meaningful way. There is a substantial risk that for many companies, the SDGs will end up being not much more than a communication tool.

We offer three reasons why businesses are not engaging more meaningfully with the SDGs. The first is the prevalence of a corporate model that sees disproportionate emphasis on shortterm financial incentives, and hence provides skewed incentives for SDG engagement. The second is the lack of greater collective action by business to help deal with markets that punish first movers and enable free-riders. And finally, the closing of civil society space in many parts of 
the world, accompanied by retreating governance, has meant many of the voices that would normally hold the private sector to account are muted.

We hold that meaningful business action on the SDGs requires a more holistic and ambitious approach that goes beyond 'business as usual'. This starts with companies re-examining their social purpose and impact, changing the performance goals and incentive structures of the business and employees, and considering wider stakeholder concerns (including those of affected communities or women in value chains, for example) in business analysis and decision making.

This paper presents five key propositions for companies in their engagement with the SDGs, including examples of good practice. The propositions are indivisible and progress on the goals requires movement on all of them.

1. Prioritization: Prioritization of SDGs should be based on the areas where companies have the greatest SDG impact (direct and indirect, positive and negative) and be grounded in transparent and robust analysis and inclusive consultations.

2. Integration: SDG engagements should build on existing corporate sustainability strategies as a baseline to determine gaps in SDG impact areas that companies can address.

3. Ambitious action: Companies should aim higher in terms of degree and scale of change to meet the ambition of the SDGs. Ambition is also reflected in a company embracing thorny issues and tackling root causes.

4. Human rights and gender equality: Enabling the advancement of the rights of women, workers and communities around the world should be the basis and core objective of companies' SDG engagement.

5. Reporting and accountability: Companies should be transparent about what they want to achieve and how they plan to get there when engaging with the SDGs. 


\section{INTRODUCTION}

In September 2015, 193 UN member states adopted the 2030 Agenda for Sustainable Development and its Sustainable Development Goals (SDGs) as the primary framework to move the world towards a more prosperous, equitable and sustainable future. The SDGs are a set of interconnected goals, and are the blueprint to achieve a better and more sustainable future for all. They address the global challenges we face today - from spiralling inequality, a climate crisis out of control, abuse of women's rights, growing environmental challenges and more. Throughout the SDG development and adoption process, it was stressed that business would have to play a key role in delivering the 17 goals by 2030, as an engine of economic growth and employment, and as a source of finance, technology and innovation. ${ }^{1}$

Three years since the adoption of the SDGs, we see a mixed picture of business engagement in the goals. While there has been an increase in the number of companies lending support to the SDG vision ${ }^{2}$ and new SDG partnership initiatives involving business have been set up, ${ }^{3}$ companies' engagement has been far from consistent. Furthermore, information on how the business community is translating the SDGs into concrete objectives, strategies and actions is still patchy. The gap between the expectation that business would help to deliver the SDGs and evidence of business taking up that challenge poses a significant risk to the achievement of the goals.

Oxfam has highlighted the risks of this divide before. In 2017, we published the Raising the Bar paper, ${ }^{4}$ which identified as a key concern the trend of companies 'cherry-picking' only the SDGs that fall within their comfort zones. Raising the Bar argued that meaningful prioritization (vs. cherry-picking) involves companies being able to demonstrate that they have gone through a due diligence process to assess where their operations and supply chain activities have the most impact. Their public explanation should highlight what was considered relevant (or 'material') and who was consulted in arriving at the priorities. We proposed a three-step process for companies: prioritizing and assessing their impact, aligning their core business strategies with the SDGs, and working towards systemic change. The paper stressed the significance of transparency and accountability, the role of private finance and the role of governments in driving business action on SDGs.

This paper aims to take this proposition further by presenting Oxfam findings from a review of how a sample of 76 companies engage with the SDGs. We analyse to what extent and how companies have sought to respond to the goals; assess the effectiveness of their engagement to date; identify barriers hindering more meaningful action; and provide examples of good practice. Please see the full methodology note for an explanation of the criteria used. ${ }^{5}$

\section{UNTANGLING THE ROLE OF BUSINESS IN DELIVERING THE SDGS}

The role of business in delivering the SDGs is not straightforward. While the SDGs rely on business contributions to be successful, business does not, at least in the short term, rely on the SDGs for its commercial success. Business incentives to engage with the SDGs do of course exist ${ }^{6}$ but they are far from universal. ${ }^{7}$ Since national governments negotiated and adopted the SDGs, they are in the driver's seat to implement the Agenda 2030, which is a state-centric framework and does not include targets or review mechanisms for business. 
In short, the SDGs require a certain level of translation to be meaningful for business. In order to untangle the role of business and deliver an Oxfam perspective on it, we have identified five distinct areas for consideration:

First is the need for prioritization. We know that companies cannot work on all the goals and therefore need to prioritize their engagements. For this prioritization to be meaningful it should be based on a company's impact (direct and indirect, positive and negative) and the impact assessment should cover the entire SDG spectrum (including SDGs that are generally considered the prerogative of states).

Second, the SDGs require integration into the long-term business goals and strategy of a company. ${ }^{8}$ For companies to make a credible contribution to the SDGs, their engagement should build on existing corporate sustainability programs and priorities as a baseline to determine gaps in SDGs impact areas that companies should address. Integration also entails ensuring that SDG contributions are not philanthropic interventions but address core business practices of both the company's operations and its supply chain.

Third, companies have to take ambitious action to meet the spirit of the SDGs. Engaging in the SDGs in a meaningful way requires the fundamental alignment of their business strategies and business models with the environmental, social and human rights ambitions articulated in the SDGs. ${ }^{9}$ Achieving that will require companies to take bold new steps and address thorny issues that hitherto have not made it onto the corporate sustainability agenda. 'Business as usual' will not enable us to the achieve the SDGs. ${ }^{10}$

Fourth, business action on the SDGs should not replace or circumvent companies'

responsibility to respect human rights and gender equality, but rather should put this at the core when prioritizing impact areas and designing strategies and interventions. The spirit of 'leave no one behind' in which the SDGs were designed will only be realized within a rightsbased framework. Implementing the UN Guiding Principles on Business and Human Rights is a good starting point for companies to help prioritize their actions on the SDGs. Similarly, business responsibility on gender equality across their operations and supply chains provides the right context for a gendered approach to the SDGs.

Fifth, companies' SDG engagement requires the aggregation and harmonization of reporting information regarding their activities, targets and progress. Many companies are already disclosing SDG-relevant information through their sustainability reporting; however, standardized SDG reporting processes and benchmarks for companies are needed in order for stakeholders to reliably assess companies' SDG performance.

Based on these key considerations, we have adopted five propositions to help us assess how meaningful SDG engagement by business has been to date. These five propositions should be central and indivisible to business engagement on SDGs. They are highlighted in the paper as follows:

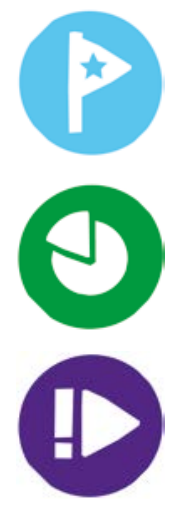

\section{Prioritization}

Integration

Ambitious action
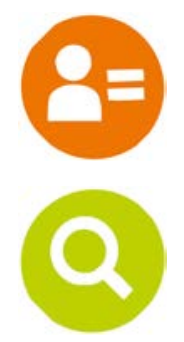

Human rights and gender equality

Reporting and accountability 
Before going further, two clarifying statements are in order. First, we recognize that business is far from homogenous in the way it approaches its role and responsibility in sustainable development. While this publication highlights trends among the companies analysed, it does not aim to generalize across the business sector.

Secondly, the SDG framework is not the only way companies can engage with sustainable development. It is entirely possible that ambitious sustainability and corporate social responsibility efforts are taking place without explicit reference to the SDGs. By focusing on companies that do reference the SDG framework, this paper analyses the degree to which the SDGs have in practice provided a relevant and useful framework for companies and have triggered business actions. 


\section{SETTING THE SCENE: KEY TRENDS FOR BUSINESS ENGAGEMENT WITH THE SDGS}

When the SDGs were adopted in September 2015, it was not clear how business would respond to the call for greater engagement. Three years on, certain trends are emerging, which we explore below.

\section{GREATER AWARENESS OF THE SDGS AMONG MULTINATIONAL CORPORATIONS}

The SDGs have shaped the rhetoric of the global business sector, particularly of multinational corporations (MNCs). The fact that most MNCs are talking about the SDGs in some way is a welcome sign. Surveys consistently find that companies' awareness and acknowledgement of the SDGs is at an all-time high. ${ }^{11}$ Similarly, the considerable number of SDG- and businessthemed events and publications confirms this trend.

However, there are two important caveats to this. First, companies' increased SDG awareness often has not filtered to all parts of the organization, but is housed within sustainability departments and top-level management. Middle management is often disconnected from the SDGs, thus limiting greater SDG integration, alignment and innovation within companies' core operations. ${ }^{12}$ Second, SDG awareness is more prevalent among large MNCs from North America and Europe compared to small and medium-sized enterprises (SMEs) and companies from non-Western countries, with some notable exceptions. ${ }^{13}$

\section{THE BUSINESS CASE AS THE PRIMARY APPEAL FOR ENGAGEMENT}

The second observation is the reliance on a business case narrative for promoting engagement with the SDGs. As the first few years of the SDG era have aimed to mobilize business support for the SDGs, appealing to the potential benefits of engagement for companies has, understandably, become a common strategy. This is best captured in the Better Business, Better World report by the Business and Sustainable Development Commission, which estimates the market potential of the SDGs at $\$ 12$ trillion (a figure which has since been cited in many other publications and discussions). ${ }^{14}$ As the report explains, 'By presenting the SDGs as a compelling growth strategy for individual businesses, the business case narrative shifts the focus from the original question, 'What can business do for the SDGs?' to asking, 'What can the SDGs do for business?'. ${ }^{15}$ 


\section{A CHALLENGING GLOBAL CONTEXT}

The creation of the SDGs was underpinned by a sense of optimism about the world's ability to achieve a more prosperous, democratic and sustainable future. Three years later the task is as daunting as ever. Global inequality has remained one of the defining issues of our time, with $82 \%$ of wealth created worldwide going to the top $1 \%$ in $2017 .{ }^{16}$ Political instability and closing civic space are threatening progress around the world. We are experiencing a 'global civic space emergency', with more than 100 countries now having laws, policies and restrictions that limit core civil society freedoms of expression, association and peaceful assembly. ${ }^{17} \mathrm{Global}$ refugee numbers have reached a record high, with a total of 68.5 million people displaced by the end of $2017 .{ }^{18}$ The world is facing an ever worsening climate crisis, with global carbon emissions predicted to rise in 2018 for the first time in four years. ${ }^{19}$ And it will take another 200 years to close the gender gap in economic participation and opportunity, educational attainment, health and survival, and political empowerment. ${ }^{20}$ This challenging global context is not lost on some in the business community, which is showing increasing awareness of and concern about the existential threats the world is facing. ${ }^{21}$

\section{CALLS FOR MORE MEANINGFUL ACTION}

Despite the scale of the challenges, cumulative progress on the 2030 Agenda has been mixed. The 2018 UN progress report on the SDGs underscored this by concluding that in important areas (e.g. electrification, child mortality) many countries are struggling to make meaningful progress due to adverse climate change impacts, conflict, inequality, and persistent poverty and hunger. ${ }^{22}$ The ambition of transitioning towards more sustainable and resilient societies remains a far-off goal for many countries and many vulnerable communities.

The mixed track record of the 2030 Agenda to date has implications for business as a key player shaping the world's ability to achieve the SDGs. This report provides a reality check on whether business engagement with the SDGs to date is sufficient, ${ }^{23}$ and points to potential ways forward to achieve more effective business engagement with the SDGs. 


\section{ASSESSING COMPANIES' SDG ENGAGEMENT}

Companies' engagement with the SDGs is difficult to assess. While the framework is only three years old, the issues at hand have long been identified and some companies have worked on them for many years through their sustainability strategies.

The absence of uniform expectations, benchmarks and reporting frameworks around companies' SDG contributions further complicates matters. ${ }^{24}$ We currently have at our disposal a wide array of standards and benchmarks to help assess companies' sustainability policies and practices. The arrival of the SDGs brings with it the impetus for an overarching framework to holistically assess and manage companies' sustainable development impacts.

There are ongoing efforts to guide companies' SDG engagement ${ }^{25}$ and how to report on it. For example, the United Nations Global Compact and GRI have led on creating a 'practical guide' for companies. This new guide offers a toolkit that aims to boost and improve businesses' reporting on the SDGs. ${ }^{26}$ However, companies continue to have significant leeway in how they communicate their work on the goals. As a result, communication can sometimes be mistaken for deeper engagement by business.

Oxfam's review of a sample of 76 companies aims to get a better idea of what companies are doing around the SDGs. We used only publicly available information to understand companies' SDG engagement. We first analysed how many companies were publicly committing to supporting the SDGs. Next, we defined five categories linked to our proposition for meaningful SDG engagement by business, as outlined in the introduction (prioritization, integration, ambitious action, human rights and gender equality, and reporting and accountability). Our findings are presented in relation to these questions:

1. SDG prioritization: Which SDGs do companies prioritize, and on what basis?

2. SDG integration: To what degree do companies utilize the SDGs as the guiding framework to determine gaps that they should address for their sustainability strategies?

3. SDG ambitions: What new targets or actions are companies taking to support the SDGs?

4. The SDGs and human rights and gender equality: To what degree do companies link their SDG engagement to their commitment to respect human rights and take a gendered approach?

5. SDG reporting: How are companies reporting on the SDGs?

Our sample included 48 global companies across a set of eight industry sectors (energy, banking, technology, agribusiness, garment, mining, food/beverage, pharmaceutical) that have a sizeable impact on sustainable development issues. ${ }^{27}$ We selected the six largest companies in these eight sectors in order to also draw sector-level conclusions about companies' SDG engagement (see methodology annex for more detail). To account for the important role that Asia plays as the world's fastest-growing economic region, ${ }^{28}$ we also analysed 30 of the largest companies headquartered in Asia in some of these sectors. Two companies overlapped across the two samples, leaving a total of 76 companies assessed for this report. Overall, there was a high degree of consistency with regards to our findings across the two groups of companies; we have therefore aggregated these findings below (while highlighting variations in findings between the two groups where they exist). 


\section{SUMMARY OF FINDINGS: MORE COMPANIES ARE PUBLICLY COMMITTING TO THE SDGS}

The good news is that the SDGs have made significant inroads into the global business community in terms of awareness and public support. The SDGs' call for business to help solve the world's greatest challenges is resonating with a significant number of companies. The majority of companies in our sample have made a public commitment to contribute to the SDGs. This finding aligns with data from other reports and surveys that have monitored SDG traction within the business community. ${ }^{29}$ The same also applies to Asia-based MNCs in our sample, although for a slightly lower percentage (57\% vs. $63 \%)$.

Companies' endorsements of the SDGs display varying degrees of urgency and detail - ranging from short statements of support within sustainability reports to stand-alone commitments to making the SDGs the central framework to guide a company's sustainability efforts. All of this shows how companies' interpretations of the SDGs' relevance can differ significantly (even within the same sector ${ }^{30}$ ), and how company engagement with the SDGs is far from universal one-third of the world's largest companies still have not publicly committed to the SDGs ${ }^{31}$ ).

Figure 1: Companies with a public commitment to supporting the SDGs

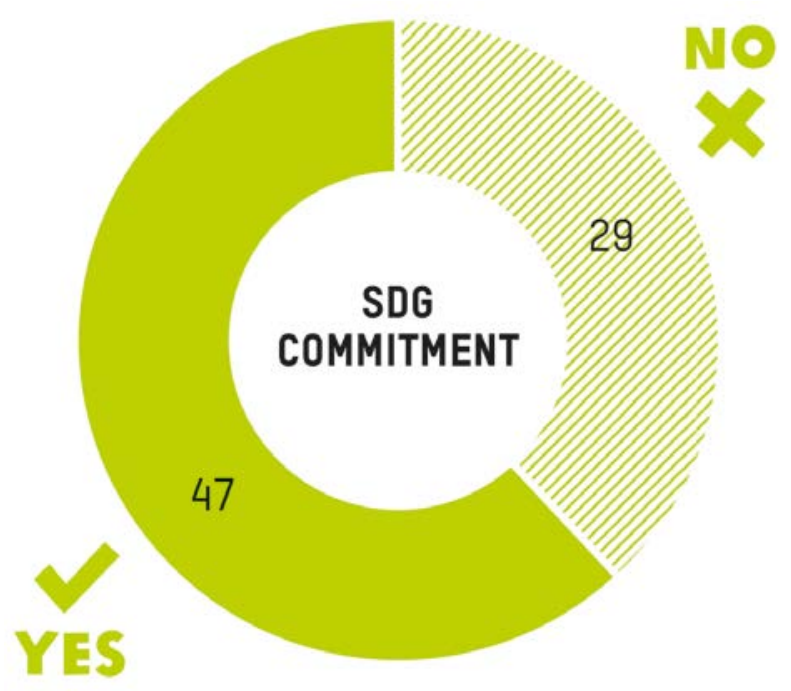

It is important to note that not engaging with the SDGs does not mean that companies have no impact on the SDGs or that they do not undertake relevant efforts. We found that almost all companies in our sample are undertaking corporate sustainability activities that are relevant to one or more of the global goals, without necessarily linking these to the SDG framework. In fact, some companies considered to be sustainability leaders in their sectors have not demonstrated any engagement with the SDGs. This observation highlights the complicated relationship between the SDGs and companies' own sustainability agendas, which we will further analyse below. 


\section{THE RISK OF CHERRY-PICKING AND THE ABSENCE OF ROBUST JUSTIFICATION FOR SDG SELECTION}

The comprehensive nature of the SDG framework requires companies to prioritize their areas of engagement. Oxfam's Raising the Bar paper ${ }^{32}$ and numerous other reports ${ }^{33}$ have highlighted the need for impact-based prioritization as a key step towards meaningful SDG engagement by business. Oxfam found in its analysis that while most companies are prioritizing a subset of SDGs, the prioritization processes appeared to have significant gaps in terms of consistency, justification and breadth.

First, our analysis uncovered a lack of consistency in how companies determine which SDGs to prioritize. Some companies have taken a very focused approach by prioritizing two or three SDGs. Others have either decided to engage with most of the goals, or do not provide any information about priority SDGs at all. As a result, there is limited sector-level consistency on SDG prioritization except for certain SDGs that companies within a sector link to very directly, e.g. food companies and SDG 2 (zero hunger), pharmaceutical companies and SDG 3 (health and well-being), or energy companies and SDG 7 (affordable and clean energy).

Overlaps in prioritization within a sector are more limited beyond these goals. While we recognize the reality of company-specific impacts that warrant variation in SDG prioritization, we are not able to determine if the variation we found is based on impact or other company-specific considerations. We are concerned about the lack of consistency within some sectors. Such consistency would allow for pre-competitive collaboration: enabling companies to tackle sectoral challenges jointly rather than competing against each other in a race to the bottom. This in turn helps to create a political space to advance policy frameworks developed by governments.

Second, we continue to see the risk of companies cherry-picking SDGs. ${ }^{34}$ We analysed companies' rationale for prioritizing certain SDGs and found that while most companies engaging with the goals provided some information on how and why certain goals were prioritized (often limited to just one or two sentences), this information was problematic for a number of reasons:

- Some companies seemed to match make their priorities based on existing priorities with no explanation beyond 'it is something [we] are already doing'. This could be a missed opportunity to use the SDG framework to arrive at a more comprehensive and fundamental realignment of business and sustainable development.

- Several companies referenced materiality (or relevance) as a key criterion for prioritization, indicated by phrases like 'material to us', 'relevant/significant to our business', or 'aligned with our business strategy'. While important, this is not enough. Where materiality is defined only by financials and financial reporting, ${ }^{35}$ this one-sided approach risks skewing priorities towards business benefits rather than also considering non-financial information such as human rights or gender impacts (positive and negative).

- There is little evidence of companies conducting due diligence processes as the basis for how they prioritize SDGs. Similarly, evidence of stakeholder input to prioritization decisions is scarce, raising the concern that stakeholders such as women, workers or communities rarely have a voice in determining priorities.

- Only a few companies made reference to government priorities as an element shaping their prioritization. This could be problematic given that the SDGs rely on the ability of governments to aggregate and align the contributions of multiple actors.

- There appears to be a lack of depth with regards to companies' engagement and understanding of the framework. For example, while many companies will state that they are contributing to SDG 8 (decent work and economic growth), their focus is on job creation and 
they do not mention key elements of this goal that include decent jobs ${ }^{36}$ or the eradication of forced labour in their supply chains. ${ }^{37}$ Explanations of prioritization rarely acknowledge the interrelations between SDGs; this reduces the potential for positive crossover effects, and also means there is a risk of actions on one goal inadvertently undermining progress on another (for example working on energy access without consideration for climate impacts).

Third, we found that SDGs with a strong but more indirect business impact have received comparatively little attention by companies - including SDGs 1 (poverty), 10 (inequality) and 16 (strong institutions) - highlighting companies' difficulties in translating their recognition of global challenges, such as inequality and democratic governance, into a priority by addressing their own broader influence on these issues.

The SDGs prioritized most frequently by companies in our sample include those with the most apparent links to business, including SDGs 8 (decent work and economic growth) and 12 (responsible consumption and production). They also include two SDGs (SDG 5 - gender equality and SDG 13 - climate change) that arguably would not have ranked high on the radar of companies only a few years ago. This finding aligns with the results of other studies and highlights interesting shifts in issue prioritization within the wider business community. ${ }^{38}$

\section{Figure 2: SDGs as prioritized by companies in this study}

\section{SDG PRIORITIZATION}
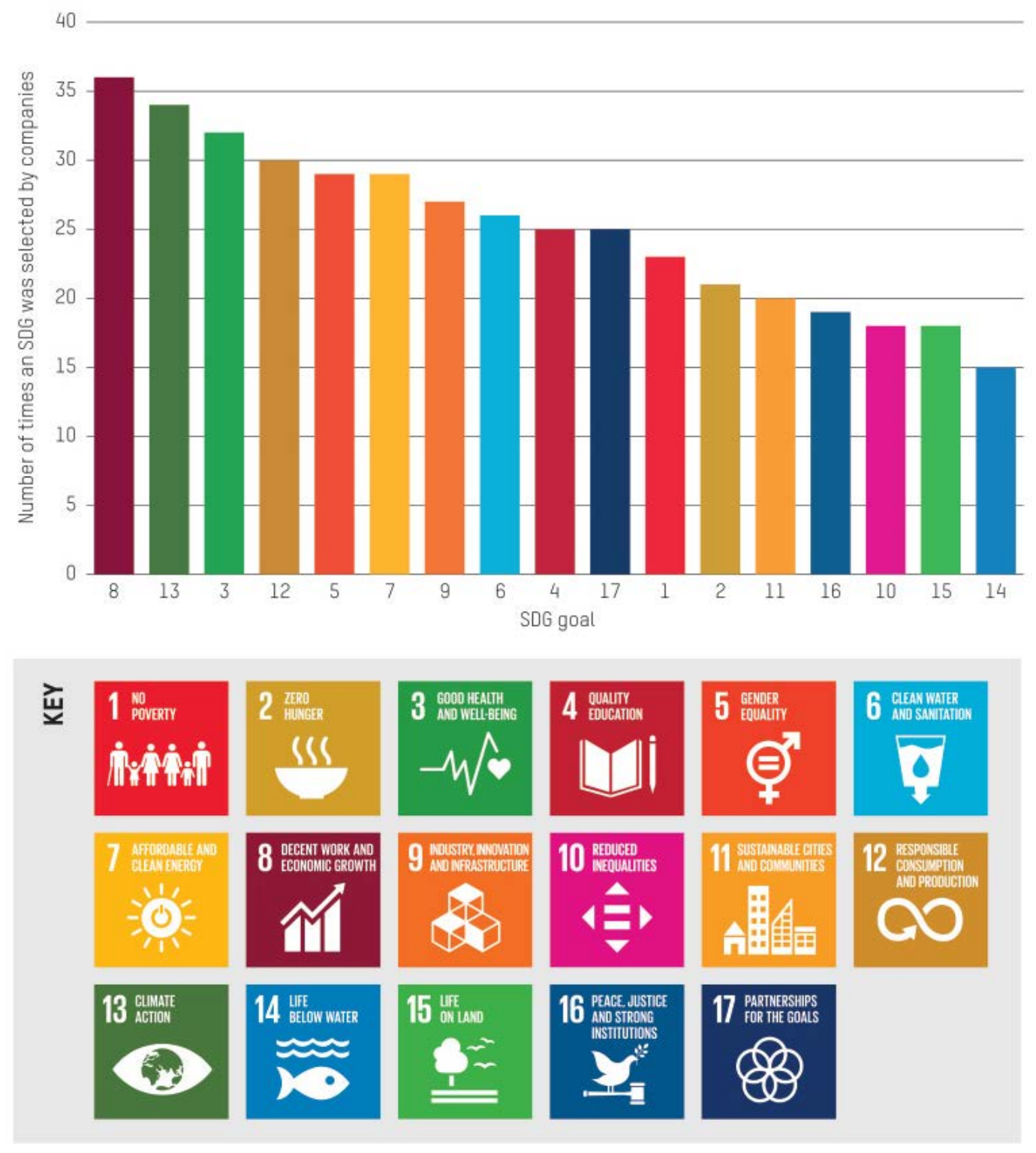


\section{UNEVEN PROGRESS ON INTEGRATING THE SDGS INTO COMPANY STRATEGIES}

For SDG engagement to be more than window dressing, companies need to integrate SDG engagement into their core business and sustainability practices. Most companies we analysed have made some progress on integration, particularly by linking, mapping and aligning the presentation of their sustainability strategies with the SDGs. However, progress has been inconsistent.

We assessed 76 companies, of which 47 stated they support the SDGs. Of the subset of 47 companies in our sample that have stated they support the SDGs, we found that more than $40 \%$ (21 of 47 ) only loosely link their sustainability strategy with the SDGs. Companies in this group made the link by merely mentioning the SDGs in the introduction to their sustainability reports or in relation to sustainability areas (e.g. by placing an SDG icon next to sustainability priorities) but without articulating how their strategies are aligned to help meet the goals. These companies risk paying lip service to the SDGs without meaningfully grappling with the goals' implications for their business and sustainability strategies.

A second significant group of companies within the subset referencing the SDGs (51\% or 24 of 47) has gone a step further by more clearly linking their sustainability strategies with the SDGs. The most common approach is for companies to map and align their sustainability priorities across the SDGs and list concrete activities and initiatives. Only two companies in our sample are using the SDGs as the guiding framework for their sustainability strategy and showing efforts to realign their practices to meet the ambition of the goals.

This finding highlights the absence of strong evidence that companies are modifying their sustainability strategies based on a commitment to and analysis of the SDGs. This weakens the potential of the SDGs as a vehicle for more comprehensive and fundamental realignment of corporate sustainability and sustainable development, including the alignment of core business processes (e.g. wages, pricing, tax) with the SDGs.

Figure 3: SDG integration into corporate sustainability strategies

\section{\ LEVEL OF INTEGRATION}

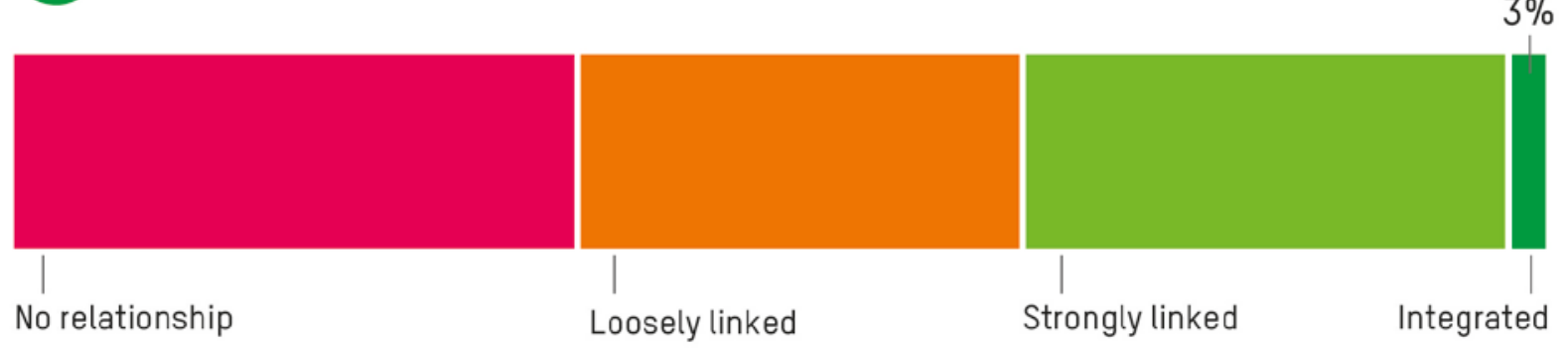

\section{A LACK OF NEW AMBITIONS}

The key test for the significance of business engagement with the SDGs is whether they catalyse new and more ambitious actions by companies. However, identifying new actions and ambitions of companies around the SDGs is inherently difficult, as some SDG-labelled actions may in fact be repackaged communications and initiatives that existed prior to the adoption of the SDGs. 
While about two-thirds of companies in our total sample (47 of 76) have made a commitment to supporting the SDGs, only one-third of companies in the total sample (24 of 76) have information available on new SDG-related actions or targets. This finding is in line with the results of other assessments, which have found that few companies have set specific and measurable targets on their SDG commitments. ${ }^{39}$

Even when we could detect new initiatives explicitly linked to the SDGs, they tended to be discrete and limited in scope. Overall, annual sustainability reports give little evidence of companies launching new and transformative sustainability initiatives because of their commitment to the SDGs.

Figure 4: Companies' SDG commitments vs. their new SDG actions

\section{SDG COMMITMENT VS. NEW ACTION}

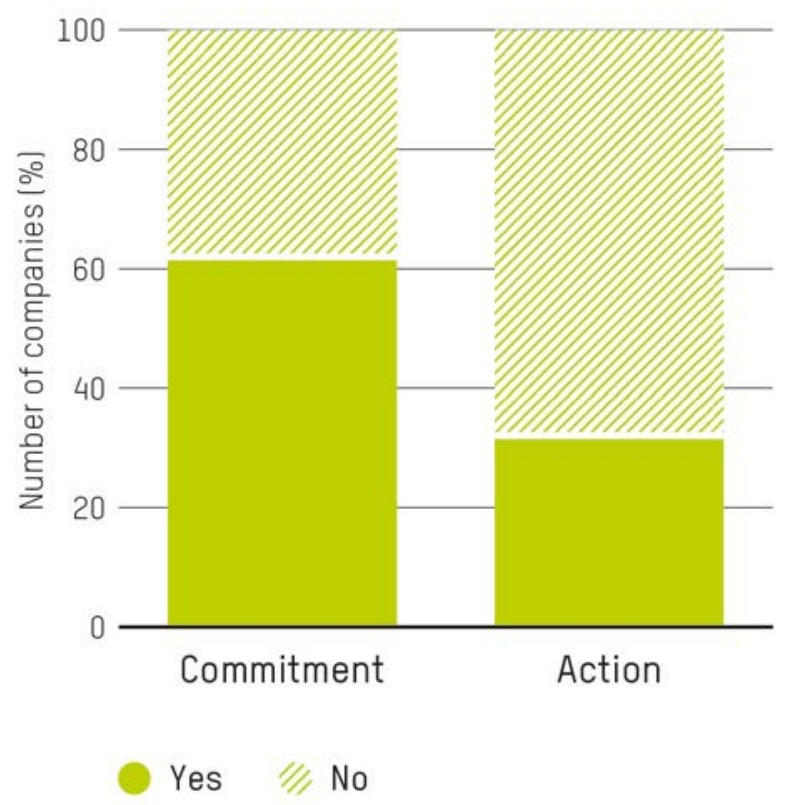

It is important to note that all the companies in our sample have existing (and in some instances ambitious) sustainability targets that are relevant to the SDGs. However, companies' annual reports show that many of these targets predate the SDGs and are not necessarily aligned with the SDGs in terms of timeline or issue focus. We only found two companies in our sample that have made explicit SDG adjustments to their existing sustainability targets and timelines by adding 2030 ambitions in line with the SDGs.

\section{THE MISSING LINK WITH THE HUMAN RIGHTS AGENDA AND GENDER EQUALITY}

In order to achieve gender equality and empower all women and girls, we must deal with the underlying issues that hold women back. While the gender equality goal was frequently selected by companies in our total sample, a review of the available information on the projects they have undertaken or are working on found that gender equality efforts focused disproportionately on increasing numbers of women, rather than quality of engagement on the issue. Notably, there was little reference to closing the gender pay gap, or actively rooting out all forms of discrimination in the workplace. Many gender equality initiatives failed to recognize that unpaid care work and social norms are substantial barriers to gender equality. 
Ensuring greater respect for human rights is one of the most important SDG contributions that businesses can make. ${ }^{40}$ Putting human rights at the heart of SDG engagement helps companies to create a people-centred approach in the SDGs' spirit of 'leave no one behind'. Importantly, respect for human rights means seeing them as more than just a matter of compliance. Viewing the issues through a human rights lens fundamentally changes how companies analyse sustainable development problems, prioritize them, attribute responsibilities, set targets and design interventions. Respecting human rights does not mean only minimizing negative impacts; it means enabling positive outcomes by creating a more conducive environment in which human rights can be realized. ${ }^{41}$

To date, the responsibility businesses have to respect human rights has remained largely detached from the SDG conversation. While the UN Guiding Principles on Business and Human Rights (UNGPs) provide a robust framework for businesses to implement this responsibility, few companies are marrying their human rights commitment with their ambition to contribute to the SDGs. Only five companies in our sample have placed a strong emphasis on human rights when articulating their support for the SDGs by publicly recognizing the importance of meeting human rights commitments in order to meaningfully contribute to the SDGs.

This does not mean that companies do not support human rights. In fact, more than $90 \%$ (28 of 30 companies) of global companies in our sample that are engaging with the SDGs have a human rights policy and report that they are addressing human rights issues through their sustainability strategies. The same is true for $65 \%$ (11 of 17) of the Asian companies in our sample engaging with the SDGs. Yet there is scarce evidence that companies are applying a human rights lens when designing and implementing their SDG engagement (e.g. making reference to human rights principles and standards, conducting human rights due diligence and impact assessments, or establishing grievance mechanisms).

\section{Figure 5: Companies explicitly linking SDGs with human rights}

\section{HUMAN RIGHTS POLICY VS. THE SDGS}

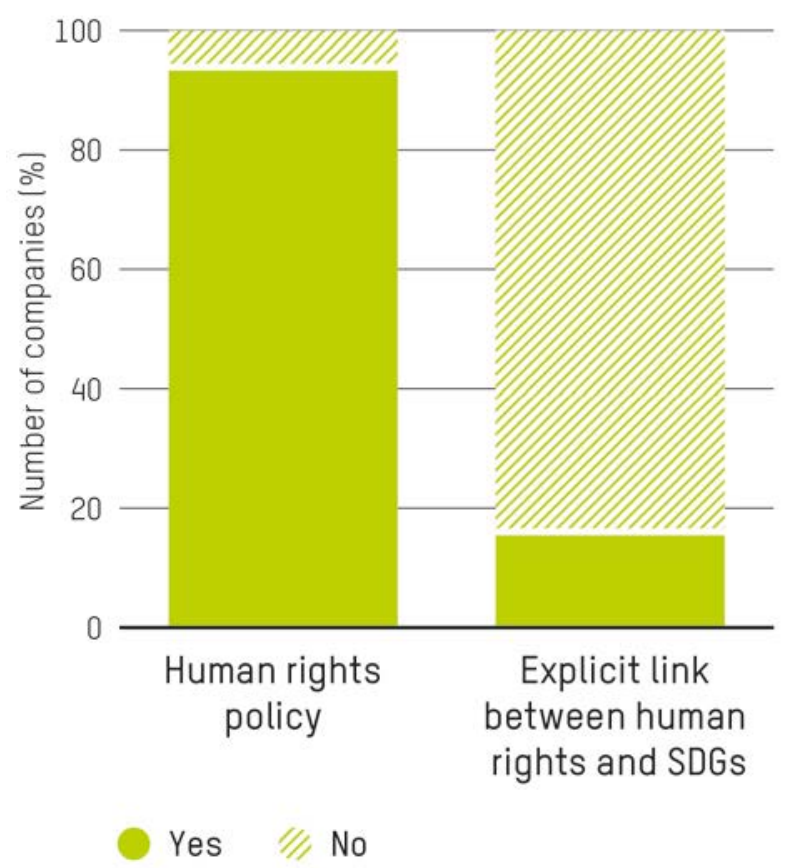




\section{REPORTING: GAPS IN TRANSPARENCY AND ACCOUNTABILITY}

How companies should report on their SDG contributions has been one of the key questions concerning the role of business in the SDGs. An increasing number of guidance documents exist $^{42}$ that aim to support businesses with designing and communicating their SDG engagement. Similarly, several global-level initiatives are underway that aim to develop reporting frameworks and benchmarks for business and the SDGs. ${ }^{43}$

From our review, it is clear that companies and supporting organizations are paying more attention to reporting on how they are contributing to meeting the SDGs. Companies appear to increasingly recognize the value of collecting and externally communicating information that is aligned with and relevant to the global goals. More than two-thirds of companies in our sample engaging with the SDGs are publishing some kind of reporting information on this engagement.

Nevertheless, quantity does not equal quality when it comes to SDG reporting by companies. Agreeing on a robust and consistent framework for assessing businesses' SDG contributions is critical to facilitating more effective monitoring and the ability to monitor, align and aggregate companies' efforts. Since SDG reporting mechanisms and frameworks are still in their infancy, it is not surprising that companies' current SDG reporting has remained inconsistent.

We detected three ways in which companies are reporting on the SDGs. First, some companies are including information on their SDG engagements in their sustainability reports. This information is often project-specific, focused on the activity level and disconnected from companies' other sustainability reporting data. Second, companies are submitting information pertaining to their SDG engagements through existing reporting mechanisms (e.g. the Global Reporting Initiative, the UN Global Compact). This approach relies exclusively on existing reporting data, but maps it across companies' SDG contributions.

Only a small number of companies are reporting on the SDGs with information regarding their contributions to specific SDG targets. This finding echoes a recent report by the World Business Council for Sustainable Development (WBCSD), which found that only $6 \%$ of company reports have aligned their strategy and targets to specific target-level SDG criteria and measured their contributions to specific SDGs. ${ }^{44}$ Current business practice thus falls far short of best practice guidance on SDG reporting, which requires orientation and alignment with the SDGs when it comes to target-setting and measurement. ${ }^{45}$ 
Box 1: From global goals to national action - business engagement with the SDGs in India

The successful realization of the SDGs globally is contingent on how successfully countries deliver on their national SDG commitments. As part of the study we looked at India, the fastest-growing economy in the world. ${ }^{46}$ In stark contrast with the country's strong economic growth, the recent SDG Index and Dashboards report ranked India 116th out of 157 countries with respect to the SDGs, with a score of 58.1 out of $100 .{ }^{47}$ Similarly, India ranks poorly on the Human Development Index and the Global Gender Gap Index, ${ }^{48}$ and has the largest number of malnourished children in the world. ${ }^{49}$

Indian business is at the forefront of India's economic growth path: 58 Indian companies are in the Forbes Global 2000 list of the world's largest public companies. ${ }^{50}$ To assess the progress made by businesses on the SDGs at the national level, we selected seven Indian companies from the Forbes list across different sectors. Following a similar methodology and approach used for the companies in our global sample, we assessed publicly available information about the Indian companies on the SDGs.

In line with our global and regional-level findings, companies in India were found to have significant awareness of and interest in the SDGs. Six out of the seven Indian companies assessed have a value statement about the SDGs.

Sustainability reporting among large Indian companies is relatively common. The top 500 companies listed on Indian stock exchanges are required to publish a sustainability disclosure report every year. In this context, all seven companies assessed report on issues related to the SDGs, although this is not framed explicitly as SDG reporting. Indian companies have shown consistent improvement in disclosures in the areas of nondiscrimination in the workplace and community development but lag behind on inclusiveness in supply chains and community stakeholder engagement. ${ }^{51}$ The national guidelines on the social, environmental and economic responsibilities of business are being revised, ${ }^{52}$ and the draft revised guidelines refer to the SDGs as one of the key resources.

It is important that the business responsibility-reporting framework ${ }^{53}$ aligns with the national SDG reporting framework. ${ }^{54}$ The draft SDG indicator framework developed by the Indian government does not currently have specific indicators to measure the role of business in achieving the SDGs, other than in terms of financial contribution. Without the integration of business reporting on sustainability and the country's SDGs reporting framework, it will be difficult to monitor the country's progress on the SDGs. 


\section{BUSINESS AND THE SDGS: CLOSING THE GAPS}

The findings outlined in the previous section paint a mixed picture. While an increasing number of the world's largest companies are expressing awareness of and support for the SDGs, we found little evidence in our review of the SDGs changing companies' sustainability strategies in meaningful ways with regards to priorities, ambition or transparency. Instead of the global goals shaping business, in many cases business appears to be attempting to reinterpret the SDGs by fitting them into existing sustainability strategies and initiatives.

Analysis and alignment are important first steps in how companies can work to meet the SDGs. However, three years after the adoption of the goals, there is a substantial risk that for many companies the SDGs will end up being not much more than a communication tool. Without greater ambition, progress towards achieving the ambition of the SDGs and their disruptive message to companies about the 'end of business as usual' will be compromised. ${ }^{55}$ The transformative vision of the 2030 Agenda requires a global economic model that works in the service of sustainable development, presupposing a policy and regulatory environment that enables companies to align their business models and strategies with the world's sustainable development ambitions.

\section{BARRIERS TO MORE MEANINGFUL SDG ENGAGEMENT BY COMPANIES}

We identified three primary reasons why businesses are not engaging more meaningfully with the SDGs:

\section{Unclear expectations}

The SDGs have remained a difficult framework for business to grapple with. Designed and adopted primarily by governments, the 2030 Agenda explicitly defines a role for business as a contributor to the global goals. Yet it has remained vague when it comes to articulating clear expectations for business. Companies in search of benchmarks or aspirations to work towards are trapped between the SDG targets (which are aimed at governments) and existing sustainability standards (many of which are more focused on baseline expectations). Initiatives such as the World Benchmarking Alliance ${ }^{56}$ or the Global Compact's Action Platform on SDG Reporting ${ }^{57}$ can be important mechanisms to create shared expectations on meaningful SDG engagement, but these are still in the early stages of development and implementation.

\section{Skewed incentives}

The lack of more meaningful SDG engagement by companies is also rooted in disproportionate emphasis on short-term financial incentives. Not all the decisions and investments necessary for achieving the SDGs will result in an easily monetizable return. ${ }^{58}$ Paying a fair share of taxes, paying a living wage, respecting a community's land rights or reducing carbon emissions might in fact be associated with negative impacts for financial shareholders in the short term, ${ }^{59}$ even if they have a positive impact on society. ${ }^{60}$ 
Companies can face significant deterrents when trying to make unilateral progress on the SDGs, as the so-called 'first-mover advantage does not always materialize. ${ }^{61} \mathrm{~A}$ number of companies employ a 'fast-follower' strategy, meaning that they are able to enjoy the fruits of sustainability investments made by other companies without carrying the same risks. ${ }^{62}$ Overcoming incentive barriers on SDG leadership will require creating a level playing field for companies (through precompetitive collaboration and public regulation) to limit the risk of competitive disadvantages.

\section{Insufficient stakeholder pressure}

In the absence of sufficient internal motivation, companies can be mobilized through external pressure. Strong government leadership in setting and driving national agendas on the SDGs can help generate more meaningful business actions. This applies to defining priorities, setting benchmarks, ensuring a level playing field to galvanize companies' contributions to the SDGs, and helping to coordinate and harmonize these contributions. While the idea of partnership between governments and the private sector is a central element of implementing the SDGs, the term risks becoming a cliché if it is not based on governance and policy leadership from governments. ${ }^{63}$

More meaningful SDG action is also hampered by the fact that it is increasingly difficult for civil society to put pressure on business. Civil society engagement on the SDGs (and the role of business in achieving them) has remained limited to date. ${ }^{64}$ This is problematic since much of the progress made in corporate sustainability over the past two decades was triggered by calls from civil society campaigns and advocates. Yet civil society groups in many countries are experiencing a 'global civic space emergency': 65 more than 100 countries have imposed laws, policies and restrictions that severely limit the space for civil society to operate and citizens to speak out or to hold governments and business accountable. ${ }^{66}$

Another external limitation is the pressure investors put on managers to prioritize short-term earnings. To date, many firms have struggled to justify investing in the SDGs due to the 'tyranny of short-termism'. ${ }^{67}$ For example, Unilever, in the wake of the attempted unsolicited Kraft Heinz takeover, was forced to make compromises on its sustainability ambitions to retain investor support. ${ }^{68}$ This highlights how the primacy of shareholder interests in corporate decision making remains a significant barrier to corporate sustainability. ${ }^{69}$ While some investors are starting to urge companies to increase their contributions to society ${ }^{70}$ and support investment decisions based on companies' SDG performance, ${ }^{71}$ there are few usable tools at hand to help investors prioritize companies which demonstrate a more fundamental alignment with the SDGs.

Acknowledging these obstacles does not absolve companies of their responsibility to contribute to the SDGs. Rather, it increases the onus on businesses to take a more considered approach and commit to the SDGs' vision and ambition. 


\section{SHINING A LIGHT ON GOOD PRACTICE}

We believe there is an urgent need for business to raise its ambition regarding its contributions to the SDGs. There are encouraging examples of companies meaningfully engaging with the SDGs, which demonstrate that a more constructive role for business is possible. They include examples of individual companies, as well as companies working together to address key social issues. This section presents a range of these examples.

Good practice actions are those that harness companies' potential to make the greatest impact. They recognize the complex nature of the SDGs and have the ambition to tackle root causes of sustainable development problems through new actions. They acknowledge the interrelation between the goals and the fact that we must succeed on all the SDGs if we are to achieve any of them.

We also shine a spotlight on issues that have had little mention or where initiatives consistently skim the surface of the issue at hand. These include gender equality, respecting and promoting human rights, responsible tax practices, tackling value/profit distribution and paying a living wage, which relate to SDGs 1 (no poverty), 5 (gender equality), 8 (decent work and economic growth) and 10 (reduced inequality).

We put equal emphasis on companies both saying and doing the right thing. Private sector actors should use their public visibility and their often-influential relationships with government and peers constructively and avoid a race to the bottom on governance and public policy. They should announce commitments publicly and provide full disclosure. This is essential for holding them to account. Particularly on issues of governance, a company should be able to align its actions and its words, for example by leaving trading associations that lobby against greater regulation on carbon emissions or on corporate transparency and accountability.

The following section looks beyond our sample of 76 companies and draws on Oxfam's extensive development and private sector experience to find evidence of good practice in support of meeting the SDGs. The examples below do not constitute an endorsement of the companies mentioned. Most of the examples relate to only one or two of the five propositions, whereas progress on the goals requires movement on all of them. Nevertheless, they still represent positive cases that, if multiplied across more companies and sectors, will help accelerate progress towards the SDGs. Some of the initiatives we discuss began before the adoption of the goals.

The examples are grouped around our five propositions for more effective business engagement with the SDGs: prioritization, integration, ambitious action, human rights, and reporting and accountability. 


\section{PRIORITIZATION P}

Our criteria for meaningful SDG prioritization are that a business:

1. Bases its prioritization on a comprehensive analysis of its SDG impact (positive and negative);

2. Includes input from affected stakeholders such as women, workers, farmers and communities in supply chains;

3. Ensures publicly available justification for why and how prioritization was decided.

\section{The business ensures publicly available justification for why and how prioritization was decided.}

Telefonica: ${ }^{72}$ Prioritization of SDGs requires companies to grapple with the complex relationship between their operations, supply chains and sustainable development. Telefonica applied a systems analysis to understanding the links between different SDGs and the company's core business. The result was a networked map of 12 SDGs, including three different levels of prioritization. Using a network approach helped the company to understand the interconnectedness of different SDGs as they related to the company's business model and strategy. The company consulted with both internal and external stakeholders to arrive at its SDG prioritization, and has been working to develop key performance indicators (KPIs) and targets for its priority areas.

Lavazza reports that it began an SDG prioritization process by mapping its existing activities according to the SDGs framework, analysing where the company has an impact along its supply chain, and to identify key gaps and areas for improvement. Stakeholder consultations revealed water usage and impacts (SDG 6) to be a key issue. This process is also part of a broader strategy by Lavazza of disseminating the message and mobilization around the SDGs, which it calls 'Goal Zero'. ${ }^{73}$ The company will use its 2018/19 report to detail its plans to engage more stakeholders, primarily civil society, suppliers and people who live in the communities in which it operates, in order to ensure that women, producers and workers are heard. ${ }^{74}$

\section{INTEGRATION (-)}

Our criteria for assessing effective integration are:

1. Companies integrate the SDGs into their core business strategies;

2. Companies use the SDGs as a framework to identify gaps and misalignments of existing sustainability strategies;

3. Companies integrate their efforts around the SDGs into collective efforts at a sector or national level. 
Businesses play a central role in the achievement of SDG 8 through their ability to provide employment and create economic value. The ambition of SDG 8 will need to be matched by companies' willingness to look at how core commercial policies and practices around wages and tax are affecting progress towards the SDGs.

Through the creation and enabling of decent jobs that pay a living wage, companies can play a role in sustainable development. Oxfam believes that access to decent work on a living wage is a fundamental pathway out of poverty, and one of the best ways to counter growing inequality. Oxfam research over the years has shown that a great deal of workers, mostly women, are working very hard but are still trapped in poverty -even though they are part of profitable supply chains. ${ }^{75}$ No matter how hard many people work, they cannot work their way to a better life and have little or no representation in the workplace. ${ }^{76}$

Around the world, corporate tax avoidance is contributing to inequality. The poorest women are hardest hit when public services they rely on are cut. For example, women disproportionately bear the burden of providing care for loved ones when health systems fail. Even when not acting illegally, corporations can use sophisticated tax planning to take advantage of a broken system that allows MNCs from many different industries to get away with avoiding taxes. ${ }^{77}$ To contribute to sustainable development and associated economic growth, it is imperative that businesses comply with the spirit as well as the letter of the tax laws and regulations of the countries in which they operate. Adopting fairer and more responsible tax and pricing practices would help to ensure that they are playing a part in both reducing poverty and creating more just future for all. ${ }^{78}$

\section{Companies integrate the SDGs into their core business strategies.}

Living Wage Foundation: In the UK, there are now nearly 5,000 organizations signed up as accredited Living Wage Employers. These employers commit to paying the Living Wage and to promoting the Living Wage using the Living Wage Employer Mark. The experience for employers who have adopted the Living Wage has been a universally positive one, with excellent results for staff retention, morale and productivity. ${ }^{79}$

Malawi Tea 2020: The Malawi Tea 2020 programme is an action-oriented coalition of Malawian tea producers, trade unions, the largest international tea buyers, relevant certification standards, NGOs and donors. The cross-sector collaboration aims to achieve a competitive, profitable tea industry that can provide for living wages and living incomes, and improved nutrition for its workers, by $2020 .{ }^{80}$ Notably, in 2016 , the first-ever collective bargaining agreement was concluded between the Tea Association of Malawi and the Plantation and Agricultural Workers Union. ${ }^{81}$

The Fair Tax Mark assesses companies on their tax practices. It measures their transparency, the quality of their tax disclosures and the rates of tax they pay. Companies such as Lush and the Co-op have taken positive steps. ${ }^{82}$ These efforts should be accompanied by companies publicly supporting calls for increased revenue transparency and financial disclosure laws to help drive greater government action on these issues. 


\section{Companies use the SDGs as a framework to identify gaps and misalignments in existing sustainability strategies.}

Unilever: In 2010, before the adoption of the SDGs, Unilever launched the Unilever Sustainable Living Plan (USLP), a blueprint for sustainable growth which responds to the challenges and opportunities of an increasingly resource-constrained and unequal world. Unilever's approach to sustainability spans the value chain and is strongly aligned with the SDGs, demonstrating one way of doing business that aims to deliver growth while minimizing negative impacts on people and the planet. ${ }^{83}$

Nestlé has made the SDGs the central framework of its sustainability strategy. The company has mapped its material issues against the SDGs to identify areas of positive and negative impacts and to see where its activities are most able to contribute to the goals. It has also introduced a set of SDG ambitions for 2030 to complement its existing 2020 commitments and to mirror the time span of the global goals.

\section{AMBITIOUS ACTION D}

Our criteria for measuring ambitious action by companies are:

1. Public commitment to tackling root causes in order to drive systemic change;

2. Long-term goals and targets that align with and directly contribute to the SDGs;

3. Design and implementation of new policies and programmes to achieve these goals and targets.

Box 3: Spotlight on gender equality (SDG 5)

Across the world, women make a significant contribution to global supply chains, despite complex hurdles that limit their inclusion and their leadership. The UN High Level Panel on Women's Economic Empowerment (HLP) recently identified seven key drivers to increase women's economic empowerment and overcome entrenched barriers. The panel has called on governments, private sector companies and civil society organizations to step up their work on women's economic empowerment by increasing investment, finding new types of partnerships and expanding their actions to more of the 'drivers.' Two of these drivers are highlighted below: Driver 1 (tackling adverse norms and promoting positive role models), and Driver 5 (changing business culture and practice). ${ }^{84}$ Businesses can and should play a role by adopting and implementing policies that prevent gender-based discrimination. Ambitious action requires businesses to go beyond superficial interventions and embed the solutions within a company's DNA. For example, on SDG 5 (gender equality) we need to see more companies supporting women's employment, striving for gender balance across the business and supply chain (including women-run businesses), and proactively increasing the number of women in managerial and leadership roles.

\section{Public commitment to tackling root causes in order to drive systemic change}

The Unstereotype Alliance ${ }^{85}$ is an industry-led initiative convened by UN Women to end harmful stereotypes that are often perpetuated through advertising. It aims to focus on the widespread adoption and implementation of measurement tools that help brands to tackle stereotypes, the expansion of evidence and advocacy, and the growth of its membership to 
catalyse the movement towards realistic, non-biased portrayals of women and men. The initiative is a starting point for challenging and transforming the negative and harmful norms that limit women's access to work and that often devalue their work - vital to achieving women's economic empowerment.

\section{Long-term goals and targets that align with and directly contribute to the SDGs}

Divine Chocolate, through the cocoa farmer organization Kuapa Kokoo, ${ }^{86}$ has prioritized equal participation and equal access for women since its founding. Women learn a range of income-generating skills and are encouraged to take positions of responsibility throughout the organization. The positive effects of these efforts ripple out beyond those directly affected and into wider society. When women are provided with training and entrepreneurial opportunities in distribution networks, it can boost local economies.

\section{Design and implementation of new policies and programmes to achieve these goals and targets}

As part of its contribution to SDG 1 (zero poverty), Mars Incorporated recently declared the long-term ambition that 'everyone working within our extended supply chain should earn sufficient income to maintain a decent standard of living'. To translate this commitment into reality, the company launched the Farmer Income Lab ${ }^{87}$ - a collaborative 'think-do tank' to help the company identify income barriers faced by farmers, design and test solutions to raise farmer incomes, and to inspire action by others. Recognizing that poverty is systemic in global food value chains, the Lab is mobilizing support from a diverse set of stakeholders ranging from academia and the private sector to non-profit organizations, including Oxfam.

\section{HUMAN RIGHTS AND GENDER EQUALITY 8}

All business engagement with the SDGs must be grounded in human rights and gender equality. Our criteria for assessing this are:

1. Strong commitment to and implementation of the UN Guiding Principles on Business and Human Rights;

2. Explicit references to and links between SDG strategy and human rights policies;

3. Concrete initiatives that tackle the most salient (most severe) risks to people and planet in company operations and value chains;

4. Strong commitment to and implementation of the UN Women's Empowerment Principles. 88

\section{Strong commitment to and implementation of the UN Guiding Principles on Business and Human Rights}

Marks \& Spencer (M\&S) has made an explicit commitment to respecting internationally recognized human rights standards - the UNGPs - applying the principles in its supply chains and operations. ${ }^{89}$ This prioritization and impact assessment has been followed up by public reporting. In 2016, M\&S published its first-ever report on human rights. In 2017, M\&S was ranked as the top retailer and second-best company overall by the inaugural Corporate Human Rights Benchmark. ${ }^{90}$ 


\section{Explicit references to and links between SDGs strategy and human rights policies}

Human rights frameworks provide companies with a people-focused lens to identify priority risks and opportunities around the SDGs. As a Tchibo representative explained, '[...] we're connecting this [our SDG engagement] back to our own human rights due diligence at the same time. If we want to secure our future as a business enterprise, we can't cherry-pick what we want to work on, including when it comes to the SDGs. We need to thoroughly look at both our positive and negative impacts on people and then take action, collectively and independently, from there.' 91

\section{Concrete initiatives that tackle the most salient (most severe) risks to people and planet in company operations and value chains}

ACT (Action, Collaboration, Transformation) is an initiative between international brands, retailers, manufacturers and trade unions to address the issue of living wages in the textile and garment supply chain. The initiative aims to improve wages in the industry by establishing industry collective bargaining in key garment and textile sourcing countries. By bringing together all relevant stakeholders, the initiative is better able to collectively address systemic labour rights abuses in the sector's supply chains. ACT is also an example of how companies addressing human rights risks in their supply chains can contribute to sustainable development. ${ }^{92}$

\section{Strong commitment to and implementation of the UN Women's Empowerment Principles (WEPs)}

The WEPs are an important first step to provide a gender-sensitive roadmap for business to advance and empower women in the workplace, marketplace and community. Gender equality is a complex area that presents a challenging agenda. After signing on, each organization will need to identify its greatest gender equality challenges and opportunities, and plan and prioritize accordingly. The principles have already been signed by approximately $2,000^{93}$ companies from all over the world. Their CEOs have signed the WEP Statement of Support and publicly pledge to work to implement the Principles.

\section{REPORTING AND ACCOUNTABILITY}

Our criteria for assessing company reporting and accountability on their SDG engagement are:

1. Robust reporting is relevant, reliable and comparable, and accessible to all stakeholders.

a. To be relevant, information crucial to assessing performance and impact is collected.

b. To be reliable and comparable, data is accurate and standardized.

c. To be accessible, all stakeholders can interact easily with the information.

2. Reporting drives accountability, with disclosure showing how companies are taking greater responsibility and demonstrating good corporate governance. 
Box 4: Spotlight on reducing inequalities (SDG 10)

The private sector sits at the centre of inequality trends due to its role in 1) creating and distributing economic value (through wages and distribution of profits to holders of capital vs. labour);94 2) paying (or avoiding paying) taxes that are essential to fund inequalityreducing public investment in health, education, and infrastructure; 95 and3) translating its economic power into political influence, thus shaping the regulatory environment in its favour. ${ }^{96}$

The benefits of economic growth disproportionately advantage the world's richest people, while governments lose critical tax revenue and more people face stagnant wage levels, and struggle to maintain or achieve a decent standard of living. ${ }^{97}$ Gender inequities exacerbate these trends, as women continue to be excluded from business ownership and corporate decision making and face discrimination related to wages, employment and access to financial services. ${ }^{98}$

\section{Reporting is relevant: information crucial to assessing performance and impact is made available to all stakeholders.}

Co-op has taken a step in the right direction by implementing reporting that assesses the distribution of economic value across stakeholder groups (employee wages and benefits, payments to providers of capital, payments to government by country, and community investments), in accordance with Global Reporting Initiative (GRI) indicator 201. ${ }^{99}$ How a company shares economic value created reflects how they are increasing or reducing financial inequalities.

\section{Reporting is reliable and comparable: data is accurate and standardized.}

The UN Global Compact and the Global Reporting Initiative (GRI) have formed an initiative, Business Reporting on the SDGs. ${ }^{100}$ The initiative comprises a Corporate Action Group and Multi-Stakeholder Advisory Committee. The aim of the intervention is to help close the gap on best practices for corporate reporting on the SDGs. The consolidated global framework will leverage the GRI standards and the 10 principles of the UN Global Compact to help businesses incorporate SDG reporting into their existing reporting and accountability processes. This will allow for comparisons between companies and will be a basis for further corporate action in line with the SDGs.

\section{Reporting is accessible: all stakeholders can interact easily with the information.}

Project Provenance $\mathbf{L t d}^{101}$ aims to empower people to change the way the global economy works, through radical transparency. The technology-driven company equips physical products with a unique ID that enables the tracking of each item throughout the supply chain, offering a means by which consumers can access verified claims. By creating and fostering open and accessible information about products, Provenance enables consumers to be active citizens through their purchasing practices. 


\section{Reporting drives accountability, with disclosure showing how companies are taking greater responsibility and demonstrating good corporate governance.}

The Corporate Human Rights Benchmark (CHRB) aims to tackle adverse impacts on workers, communities and consumers. Using the competitive nature of the market, the information provided by the Benchmark has increased visibility of corporate human rights gaps, and when used by investors has the power to raise corporate accountability and drive sustainable investment.

\section{THE WAY FORWARD}

We believe that where there is a vibrant, thriving, accountable and responsible private sector, there are greater possibilities for sustainable development and economic growth that can lead to poverty reduction and reduced inequality. Three years after the adoption of the SDGs, there is still a great deal of work for companies to do in fundamentally realigning their business strategies with the ambition of sustainable development.

Credible business engagement on the SDGs requires a more holistic and ambitious approach that goes beyond 'business as usual'. Four key avenues for more meaningful SDG engagements by companies are explored below.

\section{Moving towards fundamental realignment}

There is a significant mismatch between the urgent and complex sustainable development challenges of our time and the existing business responses and approaches to address them. We need companies to move towards a more fundamental alignment of their business model and strategy with the SDGs. This starts with companies re-examining their social purpose and impact, changing the performance goals and incentives structures of business units and employees, and considering wider stakeholder concerns (including those of affected communities, women in value chains etc.) in business analysis and decision making. This will require collaboration with peers, civil society and government to level the playing field and ensure that markets do not punish first movers and legislation prevents the undercutting of sustainable practices by less sustainable companies. Companies should engage responsibly with public policy, respecting the government's role in setting rules and standards. For example, they could use their influence to call for improved regulation of financial markets and for a system of progressive taxation in which everyone pays their fair share.

\section{Taking an impact-led approach}

Making business engagement with the SDGs more meaningful means putting impact first. Instead of companies allowing their SDG engagement to be guided by only short-term financial return, their primary criterion should be their potential to contribute to achieving the SDGs. The SDGs offer the impetus - and a unique opportunity - to analyse the sustainable development impacts of companies in a comprehensive manner. This requires looking both more widely and deeply at how companies relate to the SDGs. 


\section{Focusing on additionality}

Mobilizing more meaningful SDG engagement by business requires us to get better at identifying the actual SDG contributions of companies. It is often assumed that anything a company does around sustainability should count towards its contribution to the SDGs. However, this approach makes it difficult to assess the additional value of companies' SDG engagements. For companies to make a more credible contribution to the SDGs, existing corporate sustainability strategies should only serve as a baseline.

\section{Putting human rights at the heart of SDG engagement}

The vision of the of SDGs - articulated in the phrase 'leave no one behind' - roots the global framework in fundamental issues of human rights. Strong accountability mechanisms are crucial tools to ensure that business actions on the SDGs meet not just the letter but also the spirit of the goals. Robust reporting processes coupled with multi-stakeholder initiatives will help measure progress and correct companies' course when it is needed.

Our aspiration is that businesses will stop asking, 'What can the SDGs do for business?' and instead ask, 'What can we do for the SDGs?', by addressing the root causes underlying their sustainable development impacts. The transformative vision of the 2030 Agenda for Sustainable Development requires a global economic model that works in the service of sustainable development, with every company playing its part. We need business to work for the SDGs, in support of nation states, and in collaboration with other actors to achieve sustainable development for all. 
1 Cited in Business Fights Poverty (2015). Business and the United Nations - Working Together Towards the Sustainable Development Goals: A Framework for Action. Available at:

https://www.un.org/sg/en/content/sg/statement/2015-09-26/secretary-generals-remarks-united-nationsprivate-sector-forum (accessed 20 September 2018)

2 Ethical Corporation (2018). Top stories of 2017: \#10 Corporates embrace SDGs but prove slow to act. Retrieved 23 August 2018 from: http://www.ethicalcorp.com/top-stories-2017-10-corporates-embracesdgs-prove-slow-act

3 World Benchmarking Alliance. Corporate Sustainability Performance. Retrieved from: https://www.worldbenchmarkingalliance.org/wba/

4 N. Agarwal, U. Gneiting and R. Mhlanga (2017). Raising the Bar: Rethinking the Role of Business in the Sustainable Development Goals. Retrieved 17 August 2018 from: https://policypractice.oxfam.org.uk/publications/raising-the-bar-rethinking-the-role-of-business-in-the-sustainabledevelopment-620187

5 For details of the methodology used, please see the methodology note that accompanies this paper: https://policy-practice.oxfam.org.uk/error?aspxerrorpath=/publications/walking-the-talk-assessingcompanies-progress-from-sdg-rhetoric-to-action-620550

6 Business and Sustainable Development Commission (2017). Better Business, Better World: The report of the Business \& Sustainable Development Commission. Retrieved 23 August 2018 from: http://report.businesscommission.org/uploads/BetterBiz-BetterWorld 170215 012417.pdf

7 U. Gneiting (2017). Better business, better world? Retrieved 23 August 2018 from Politics of Poverty blog: https://politicsofpoverty.oxfamamerica.org/2017/05/better-business-better-world/

8 UN Global Compact (2017). Blueprint for Business Leadership on the Sustainable Development Goals (SDGs): A Principles-based Approach. Available https://www.unglobalcompact.org/docs/publications/Blueprint-for-Business-Leadership-on-theSDGs.pdf Retrieved 14092018

9 Institute for Human Rights and Business (2015). State of Play: Business and the Sustainable Development Goals: Mind the Gap - Challenges for Implementation. Retrieved 23 August 2018 from: https://www.ihrb.org/pdf/state-of-play/Business-and-the-SDGs.pdf

10 PwC (2015). Make It Your Business: Engaging with the Sustainable Development Goals. Retrieved 23 August 2018 from: https://www.pwc.com/gx/en/sustainability/SDG/SDG Research FINAL.pdf

11 World Business Council for Sustainable Development and DNV GL (2018). Business and the SDGs: A survey of WBCSD members and Global Network partners. Retrieved 23 August 2018 from:

https://docs.wbcsd.org/2018/07/WBCSD Business and the SDGs.pdf

12 Edie newsroom (2017). Middle-management 'disconnected' from Sustainable Development Goals, report finds. Retrieved 23 August 2018 from: https://www.edie.net/news/7/Middle-management-disconnected--from-Sustainable-Development-Goals--report-finds/

13 SDG Business Forum (2018). Programme Preview. Retrieved 23 August 2018 from: https://www.sdgbusinessforum.org/uploads/1/9/6/4/19640823/2018 sdg business forum programme web.pdf

14 Business for 2030 (2018). A Business Case for the SDGs. Retrieved 23 August 2018 from: http://www.businessfor2030.org/bizfor2030blog/2018/1/3/a-business-case-for-the-sdgs; EY (2017). Why should Sustainable Development Goals be part of every business plan? Retrieved 23 August 2018 from: https://www.ey.com/Publication/vwLUAssets/ey-why-should-sustainability-developmentgoals-be-part-of-every-business-plan/\$FILE/ey-why-should-sustainability-development-goals-be-partof-every-business-plan.pdf

15 U. Gneiting (2017). Better business, better world? Reflecting on the role of business in the SDGs, op. cit.

16 D. Alejo Vazquez Pimentel, I. Macias Aymar and M. Lawson (2018). Reward Work, Not Wealth: To end the inequality crisis, we must build an economy for ordinary working people, not the rich and powerful. Oxfam. Retrieved from https://policy-practice.oxfam.org.uk/publications/reward-work-not-wealth-to-endthe-inequality-crisis-we-must-build-an-economy-fo-620396 
17 CIVICUS (2017). State of Civil Society report 2017. Thematic Overview: Civil society and the private sector. Retrieved 26 August 2018 from: http://www.civicus.org/documents/reports-andpublications/SOCS/2017/thematic-synthesis.pdf

18 UNHCR (2018). Global Trends: Forced Displacement in 2017. Retrieved 28 August 2018 from: http://www.unhcr.org/globaltrends2017/

19 Global Carbon Project (2017). Global Carbon Budget 2017. Retrieved on August 23, 2018 from http://www.globalcarbonproject.org/carbonbudget/17/files/GCP CarbonBudget 2017.pdf

20 World Economic Forum. Insight Report. The Global Gender Gap Report 2017. Retrieved 29 August 2018 from: http://www3.weforum.org/docs/WEF GGGR 2017.pdf

21 World Economic Forum. Insight Report. The Global Risks Report 2017: 12th Edition. Retrieved 29 August 2018 from: http://www3.weforum.org/docs/GRR17 Report web.pdf

22 United Nations (2018). The Sustainable Development Goals Report 2018. Retrieved 23 August 2018 from: https://www.un.org/development/desa/publications/the-sustainable-development-goals-report2018.html

23 UN Global Compact (18 July 2018). SDG Business Forum Urged to Do Business Responsibly and Accelerate Sustainable Development. Retrieved 23 August 2018 from:

https://3blmedia.com/News/SDG-Business-Forum-Urged-Do-Business-Responsibly-and-AccelerateSustainable-Development

24 Cuff. M (11 January 2018). Are businesses only paying 'lip service' to the SDGs? Retrieved from https://www.businessgreen.com/bg/analysis/3024196/are-businesses-only-paying-lip-service-to-the$\underline{\text { sdgs }}$

25 J.L. Blasco, A. King and S. Jayaram (2018). How to report on the SDGs - what good looks like and why it matters. KPMG. Retrieved 23 August 2018 from: https://assets.kpmg.com/content/dam/kpmg/xx/pdf/2018/02/how-to-report-on-sdgs.pdf

26 GRI (2018, August 1). New guidance for companies to report their impact on the Sustainable Development Goals. https://www.globalreporting.org/information/news-and-press-center/Pages/Newguidance-for-companies-to-report-their-impact-on-the-Sustainable-Development-Goals.aspx

27 Global Commission on Business and Sustainable Development and Corporate Citizenship. (2016). SDGs \& Sectors: A review of the business opportunities. Retrieved http://s3.amazonaws.com/awsbsdc/SDG-Sectors.pdf

28 World Bank (9 April 2016). South Asia Remains World's Fastest Growing Region, but Should Be Vigilant to Fading Tailwinds. Retrieved 28 August 2018 from: http://www.worldbank.org/en/news/pressrelease/2016/04/09/south-asia-fastest-growing-region-world-vigilant-fading-tailwinds

29 Ethical Corporation (2018). The Responsible Business Trends Report 2018. Member-only access Retrieved on 23 August 2018 from: http://ethicalcorp.com/whitepapers/responsible-business-trendsreport-2018

30 Sectoral consistency is important as it allows for pre-competitive collaboration and development of policy frameworks (see section 4 for explanation).

31 Edie newsroom (10 January 2018). PwC: Businesses still not meaningfully engaging with SDGs. Retrieved from https://www.edie.net/news/7/PwC--Businesses-still-not-meaningfully-engaging-with$\underline{\text { SDGs/ }}$

32 N. Agarwal, U. Gneiting and R. Mhlanga (2017). Raising the Bar: Rethinking the Role of Business in the Sustainable Development Goals, op. cit.

33 PwC (2015). Make It Your Business: Engaging with the Sustainable Development Goals, op. cit.

34 N. Agarwal, U. Gneiting and R. Mhlanga (2017). Raising the Bar: Rethinking the Role of Business in the Sustainable Development Goals, op. cit.

35 ICAEW International Accounting, Auditing and Ethics Audit and the Audit and Assurance Faculty (2017). Materiality in the audit of financial statements. Retrieved from https://www.icaew.com/international-accounting-and-auditing/audit-planning/materiality-in-the-audit-offinancial-statements

36 A definition of 'decent work' is available from the International Labour Organization: https://www.ilo.org/global/topics/decent-work/lang--en/index.htm 
37 The definition of SDG 8 and indicators are available from the Sustainable Development Knowledge Platform: https://sustainabledevelopment.un.org/sdg8

38 UNGSII (2018). SDG Commitment Report 100 2018: SDG Commitment Report empowers investors to move from negative screening to impact investing. Retrieved from: http://mediadrawer.gvces.com.br/columbia/original/session-3-3-scr100 20184 20162017 comparison update.pdf

39 J.L. Blasco et al. (2018) How to report on the SDGs - what good looks like and why it matters, op. cit.

40 The Shift Project in collaboration with World Business Council for Sustainable development July (2018). The Human Rights Opportunity: 15 real-life cases of how business is contributing to the Sustainable Development Goals by putting people first. Retrieved 28 August 2018 from: https://www.shiftproject.org/media/resources/docs/TheHumanRightsOpportunity Shift-07-172918.pdf?utm source=website\&utm medium=button-SDGs\&utm campaign=SDGs Download-PDF

41 lbid.

42 UN Global Compact. Making Global Goals Local Business. Retrieved from: https://www.unglobalcompact.org/sdgs/sdg-toolbox

43 World Benchmarking Alliance. Corporate Sustainability Performance, op. cit.

44 L. Mead (24 October 2017). World Business Council for Sustainable Development Report Reviews Companies on Sustainability Reporting. Retrieved 28 August 2018 from: http://sdg.iisd.org/news/wbcsd-report-reviews-companies-on-sustainability-reporting/

45 Global Reporting Initiative and United Nations Global Compact. Business Reporting on SDGS. Retrieved 23 August 2018 from: https://www.globalreporting.org/information/SDGs/Pages/Reportingon-the-SDGs.aspx

46 World Bank (2018). Lifted by India, South Asia Regains Growth Lead, Still Lags on Jobs. Retrieved 23 August 2018 from: http://www.worldbank.org/en/news/press-release/2018/04/15/south-asia-focusgrowth-lead-jobless-growth-create-more-jobs

47 Bertelsmann Stiftung and Sustainable Development Solutions Network. (2018). SDG Index \& Dashboards Report 2018. http://www.sdgindex.org/overview/

48 UNDP. Human Development Index. India. Available at: http://hdr.undp.org/en/countries/profiles/IND and World Economic Forum (2017). The Global Gender Gap Report 2017, p. 22. Available at: http://www3.weforum.org/docs/WEF GGGR 2017.pdf

49 Livemint (1 November 2017). India has largest number of malnourished children in the world: Report. Available at: https://www.livemint.com/Politics/OldNvn30nqdrGQC6pARu3J/India-has-largest-numberof-malnourished-children-in-the-wor.html

50 Forbes (2018). Global 2000: The World's Largest Public Companies. Available at: https://www.forbes.com/global2000/\#6e4e79e7335d

51 Praxis, Oxfam India, Corporate Responsibility Watch (2018). Making Growth Inclusive 2018: Analysing Policies, Disclosures and Mechanisms of Top 100 Companies. Retrieved from: http://responsiblebiz.org/wp-content/uploads/2018/02/Making-Growth-Inclusive-2018.pdf

52 Ministry of Corporate Affairs, Government of India. Invitation for public comments on Draft National Guidelines on Social, Environment \& Economic Responsibility of Business (2018). Retrieved 13 September 2018 from: http://www.mca.gov.in/Ministry/pdf/DraftNationalGuidelines2018 20062018.pdf

53 Securities Exchange Board of India (4 November 2015). Format for Business Responsibility Report (2015). Retrieved 13 September 2018 from: https://www.bseindia.com/downloads/whtsnew/file/SEBI\%20Cir\%20on\%20BRR\%2004 11 2015.pdf

54 Ministry of Statistics and Planning Implementation, Government of India. Draft National Indicator Framework for Sustainable Development Goals (SDGs)-inviting the comments from general public and experts. Retrieved 6 July 2018 from: http://mospi.nic.in/sites/default/files/announcements/SDG DraftNational Indicators8mar17.pdf?downlo $\underline{\mathrm{ad}=1})$

55 W. Higginbotham (2018). The UN tells private enterprise leaders that "Business as usual won't work". Retrieved on 23 August 2018 at http://www.ipsnews.net/2018/04/un-tells-private-enterprise-leadersbusiness-usual-wont-work

56 World Benchmarking Alliance, Corporate Sustainability Performance, op. cit. 
57 Global Reporting Initiative and United Nations Global Compact. Business Reporting on SDGS, op. cit.

58 M. Blowfield (2014). Poverty's Case for Business: The Evidence, Misconceptions, Conceits and Deceit Surrounding the Business Case. International Research Network on Business, Development and Society. Retrieved from:

https://www.researchgate.net/publication/252272677 Poverty's Case for Business The Evidence M isconceptions Conceits and Deceit Surrounding the Business Case; M.L. Barnett (2016). The Business Case for Corporate Social Responsibility: A Critique and an Indirect Path Forward. Business \& Society. Retrieved from: http://journals.sagepub.com/doi/abs/10.1177/0007650316660044

59 Business representatives have acknowledged these shortcomings and stated that the main impediment to more efforts around key sustainable development issues, such as climate change, is the absence of sufficient incentives. BSR/GlobeScan/Business for Social Responsibility (2016). The State of Sustainable Business in 2016: Results from the BSR/GlobeScan Survey. Retrieved on 23 August 2018 from: https://www.bsr.org/en/our-insights/blog-view/state-of-sustainable-business-2016-results-frombsr-globescan-survey

60 N. Agarwal, U. Gneiting and R. Mhlanga (2017). Raising the Bar: Rethinking the Role of Business in the Sustainable Development Goals, op. cit.

61 Business and Sustainable Development Commission and Volans (2016). Breakthrough Business Models: Exponentially More Social, Lean, Integrated and Circular. Retrieved from: http://s3.amazonaws.com/aws-bsdc/Volans Breakthrough Business Models Report September2016-updated-4-Oct-2016.pdf

$62 \mathrm{lbid}$

63 A. Fishman (26 July 2018). Chief Sustainability Officers Exchange Lessons on Transforming Businesses. Retrieved on 23 August 2018 from SDG Knowledge Hub at: http://sdg.iisd.org/news/chiefsustainability-officers-exchange-lessons-on-transforming-businesses/

64 CPDE (18 July 2018). High awareness but limited role of civil society in SDG implementation - CPDE study. Retrieved on August 232018 from http://www.csopartnership.org/single-post/2018/07/18/Highawareness-but-limited-role-of-civil-society-in-SDG-implementation---CPDE-study

65 CIVICUS (2017). State of Civil Society report 2017. Thematic Overview: Civil society and the private sector, op. cit.

66 CIVICUS (2016). Civil Society Watch Report. Retrieved on 23 August 2018 from: http://www.civicus.org/index.php/en/media-centre-129/reports-and-publications/2449-core-civil-societyrights-violated-in-109-countries-civil-society-watch-report

67 D. Barton (2011). Capitalism for the Long Term. Harvard Business Review. Retrieved on 23 August 2018 from https://hbr.org/2011/03/capitalism-for-the-long-term

68 Edgecliff-Johnson (27 February 2018). Unilever chief admits Kraft Heinz bid forced compromises. Financial Times. Retrieved from: https://www.ft.com/content/ea0218ce-1be0-11e8-aaca-4574d7dabfb6

69 B. Sjafjell, A. Johnston, L. Anker-Sorenson and D. Millon (2014). Shareholder Primacy: The Main Barrier to Sustainable Companies. Department of Private Law, University of Oslo. Retrieved on 23 August 2018 from: https://www.jus.uio.no/ifp/english/research/projects/sustainablecompanies/news/sustainablecompanies2pagesummarycompanylaw.pdf

70 BlackRock (2018). Larry Fink's annual letter to CEOs: A Sense of Purpose. Retrieved from: https://www.blackrock.com/corporate/en-us/investor-relations/larry-fink-ceo-letter

71 Aviva (22 October 2017). Our contribution to the Sustainable Development Goals. Retrieved from https://www.aviva.com/social-purpose/contribution-to-sustainable-development-goals/

72 Telefonica. The Sustainable Development Goals. Retrieved from https://www.telefonica.com/en/web/responsible-business/sdg

73 M. Cerutti (14 June 2018). Turning a commitment into actions. OECD Development Matters blog. https://oecd-development-matters.org/2018/06/14/turning-a-commitment-into-actions/\#more-3851

74 Oxfam will follow up with Lavazza on these commitments when the company publishes its 2018/2019 sustainability report.

75 R. Willoughby and T. Gore. (2018). Ripe for Change: Ending human suffering in supermarket supply chains. Oxfam. Retrieved from: http://policy-practice.oxfam.org.uk/ publications/ripe-for-change-endinghuman-suffering-insupermarket-supply-chains-620418. DOI: $\underline{10.21201 / 2018.1787}$ 
76 R. Wilshaw, S. Hamilton, J. Théroux-Séguin and D. Gardener. (2015). In Work but Trapped in Poverty: A summary of five studies conducted by Oxfam, with update on progress along the road of a living wage. Oxfam. Retrieved from: http://policy-practice.oxfam.org.uk/publications/in-work-buttrapped-inpoverty-a-summary-of-five-studies-conductedby-oxfam-wit-578815

77 M. Fried (2018). Prescription for Poverty: Drug companies as tax dodgers, price gougers and influence peddlers. Retrieved 18 September 2018 from https://policypractice.oxfam.org.uk/publications/prescription-for-poverty-drug-companies-as-tax-dodgers-pricegougers-and-influe-620548

78 A more detailed discussion of corporate responsibilities on tax can be found in T. Boerrild, M. Kohonen, R. Sarin, K. Stares and M. Lewis (2015). Getting to Good: Towards responsible corporate tax behaviour. Retrieved from https://www.oxfam.org/en/research/getting-good-towards-responsiblecorporate-tax-behavior

79 Living Wage Foundation. What are the Business Benefits of Paying the Real Living Wage? Retrieved 23 August 2018 from: https://www.livingwage.org.uk/good-for-business

80 Malawi Tea 2020. See: http://www.malawitea2020.com/

81 Sector Network Rural Development, Africa. (20 October 2017). Progress Towards Living Wage and Living Income - Malawi Tea 2020. GIZ. Retrieved https://www.snrd-africa.net/progress-towards-livingwage-and-living-income/

82 Fair Tax Mark. Accredited Organisations. See: https://fairtaxmark.net/accredited-organisations/

83 Unilever. Our strategy for sustainable growth. Retrieved from https://www.unilever.com/sustainableliving/our-strategyl

84 UN Sectary Generals High Level Panel on Women Economic Empowerment. Seven Drivers and Recommendations. Retrieved from http://hlp-wee.unwomen.org/en/about/seven-drivers\#driver-1

85 UN Women (20 June 2018). Unstereotype Alliance celebrates its first anniversary and launches new report 'Unstereotype: Beyond Gender. The Invisible Stereotypes'. Retrieved from http://www.unwomen.org/en/news/stories/2018/6/press-release-unstereotype-alliance-first-anniversary

86 Divine Chocolate. Women's Empowerment. Retrieved 23 August 2018 from: http://www.divinechocolate.com/us/about-us/TrainingWomen

87 Mars Incorporated. Farmer Income Lab. Retrieved from https://www.farmerincomelab.com/

88 Empower Women. About Us. See https://www.empowerwomen.org/en/who-we-are/about-us

89 M\&S (2016). Marks and Spencer Human Rights Report 2016: Our approach to recognising, respecting and advancing human rights throughout our business operations. Retrieved 23 August 2018 from: https://corporate.marksandspencer.com/documents/plan-a-our-approach/mns-human-rights-reportjune2016.pdf

90 M. Lemos Stein (20 March 2017). The Morning Risk Report: A New Tracker for Corporate Human Rights. The Wall Street Journal. Retrieved 23 August 2018 from:

https://blogs.wsj.com/riskandcompliance/2017/03/20/the-morning-risk-report-a-new-tracker-forcorporate-human-rights/

91 The Shift Project in collaboration with World Business Council for Sustainable development July (2018). The Human Rights Opportunity, op. cit.

92 Ibid.

93 A list of companies which have signed up to the Women's Empowerment Principles is available at https://www.empowerwomen.org/en/weps/companies.

94 R. Willoughby and T. Gore. (2018). Ripe for Change: Ending human suffering in supermarket supply chains, op. cit.

95 M. Fried (2018). Prescription for Poverty: Drug Companies as tax dodgers, price gougers and influence peddlers, op. cit.

96 M-L Abshagen, A. Cavazzini, L. Graen and W. Obenland (2018). Hijacking the SDGs? The Private Sector and the Sustainable Development Goals. Retrieved from https://www.forumue.de/wpcontent/uploads/2018/07/SDG-und-Privatwirtschaft-Studie.pdf

97 D. Alejo Vazquez Pimentel, I. Macias Aymar and M. Lawson (2018). Reward Work, Not Wealth, op. cit. 
98 UN Women and UN Global Compact Office (2011). Women's Empowerment Principles. Equality Means Business. Retrieved from https://www.unglobalcompact.org/docs/issues doc/human rights/Resources/WEP EMB Booklet.pdf

99 Global Reporting Initiative (2018). GRI 201: Economic Performance 2016. Retrieved 23 August 2018 from: https://www.globalreporting.org/standards/media/1039/gri-201-economic-performance-2016.pdf

100 Global Reporting Initiative and United Nations Global Compact. Business Reporting on the SDGs, op, cit.

101 Project Provenance. We live in the world we buy into. Retrieved 23 August 2018 from: https://www.provenance.org/about\#mission 


\section{Oxfam Discussion Papers}

Oxfam Discussion Papers are written to contribute to public debate and to invite feedback on development and humanitarian policy issues. They are 'work in progress' documents, and do not necessarily constitute final publications or reflect Oxfam policy positions. The views and recommendations expressed are those of the author and not necessarily those of Oxfam.

This paper was written by Ruth Mhlanga, Uwe Gneiting and Namit Agarwal. Oxfam acknowledges the assistance of Helen Bunting, Lies Craeynest, Caroline Ashley, Noura Abahsain, Isabelle Morin and Justin Teo in its production.

For more information, or to comment on this paper, email Ruth Mhlanga: rmhlanga1@oxfam.org.uk.

(c) Oxfam International September 2018

This publication is copyright but the text may be used free of charge for the purposes of advocacy, campaigning, education, and research, provided that the source is acknowledged in full. The copyright holder requests that all such use be registered with them for impact assessment purposes. For copying in any other circumstances, or for re-use in other publications, or for translation or adaptation, permission must be secured and a fee may be charged. Email policyandpractice@oxfam.org.uk.

The information in this publication is correct at the time of going to press.

Published by Oxfam GB for Oxfam International under ISBN 978-1-78748-337-8 in September 2018. DOI: $10.21201 / 2018.3378$

Oxfam GB, Oxfam House, John Smith Drive, Cowley, Oxford, OX4 2JY, UK.

\section{OXFAM}

Oxfam is an international confederation of 19 organizations networked together in more than 90 countries, as part of a global movement for change, to build a future free from the injustice of poverty. Please write to any of the agencies for further information, or visit www.oxfam.org.

Oxfam America (www.oxfamamerica.org)

Oxfam Australia (www.oxfam.org.au)

Oxfam-in-Belgium (www.oxfamsol.be)

Oxfam Brasil (www.oxfam.org.br)

Oxfam Canada (www.oxfam.ca)

Oxfam France (www.oxfamfrance.org)

Oxfam Germany (www.oxfam.de)

Oxfam GB (www.oxfam.org.uk)

Oxfam Hong Kong (www.oxfam.org.hk)

Oxfam IBIS (Denmark) (www.oxfamibis.dk)

Observer: KEDV (Oxfam Turkey)
Oxfam India (www.oxfamindia.org)

Oxfam Intermón (Spain) (www.oxfamintermon.org)

Oxfam Ireland (www.oxfamireland.org)

Oxfam Italy (www.oxfamitalia.org)

Oxfam Mexico (www.oxfammexico.org)

Oxfam New Zealand (www.oxfam.org.nz)

Oxfam Novib (Netherlands) (www.oxfamnovib.nl)

Oxfam Québec (www.oxfam.qc.ca)

Oxfam South Africa (www.oxfam.org.za) 